\title{
The End of the Right to Buy and the Future of Social Housing in Scotland
}

\author{
Kim McKee \\ Centre for Housing Research, School of Geography and Geosciences, University of \\ St. Andrews, Irvine Building, North Street, St Andrews, Fife KY16 9AL, UK
}

\begin{abstract}
Thirty-years since the introduction of the Right to Buy - the most successful example of housing privatisation policy in the UK - the current Housing (Scotland) Bill proposes to end the scheme for both new social housing tenants and new social housing. This paper considers the implications of these modernising reforms, in the context of housing policy divergence post-devolution. It concludes that these proposals are likely to have a significant, but mixed, impact on the future of the social rented sector in Scotland.
\end{abstract}

\section{Introduction}

Introduced by the UK Conservative government in 1980, the Right to Buy (RTB) enabled sitting council tenants to purchase their home with generous discounts. Although the sale of public housing did occur before this time, the 1980 Housing Act (and the 1980 Tenants' Rights Etc. Act in Scotland) removed the discretionary power of local authorities and introduced a uniform national scheme based on a 'right' to buy. It also provided higher discounts to tenants based on period of residence, and gave them the right to a local authority mortgage, thus making owner-occupation more affordable. These incentives have been made less attractive in recent years.

One of the most significant and controversial housing policies of all time, the RTB has had a significant impact on changing the tenure structure in Britain (Munro 2007; Jones 2010; King 2010). Popular with both tenants and politicians it has been pivotal to the growth of homeownership in the post-war period. It has had the most dramatic impact in Scotland where levels of public housing were traditionally higher (Goodlad and Atkinson 2004; Jones 2010). Indeed, current levels of homeownership 
across the UK would have been difficult to achieve without the prior existence of a large state sector that could be 'privatised'.

Drawing on the housing studies literature and a review of government policy documents at the devolved level, this paper explores recent developments and proposed amendments to the RTB in Scotland. The paper begins by an analysis of the impacts of this policy thirty years on. It then considers how the RTB was 'modernised' by the Housing (Scotland) Act 2001 post-devolution, as well as more recent proposals outlined by the Scottish Government in the current Housing (Scotland) Bill. The paper concludes by considering the impact of these reforms for the future of social housing in Scotland, and the consequences for local communities.

\section{Evaluating the Policy 30 years on}

Thirty years on, the RTB can be evaluated as one of the most 'popular privatisations of all' (Goodlad and Atkinson 2004). Since it was introduced in 1980, over 2.5 million homes have been purchased across the UK through the scheme. Sales peaked in the late 1980s fuelled by a house price boom and an increase in discounts for flats. More recently sales patterns have been less predictable, and since 2003 have fallen dramatically because of changes to the qualifying criteria (Jones 2010) and the collapse of the housing market post credit-crunch (King 2010).

Overall, the RTB has had both positive and negative impacts upon individuals, neighbourhoods and tenures. For individuals, it clearly connected with their aspirations for homeownership and promoted a massive transfer of wealth from the state to low-income households (King 2010; see also Saunders 1990). This has been achieved not only through the availability of discounts, but through capital gains as re-sale markets have developed. An additional benefit for purchasers has been that mortgage repayments on these properties were often less in real terms than local authority rents, with re-sales enabling trading up in the owner-occupied sector (Forrest 2010). Yet as Jones notes (2010: 67), "the major criticism lies in the lottery of the process that is very much dependent on the location and type of council house occupied". Research by Forrest and Murie (1988) has emphasised the differential take up of the RTB, and the now familiar story that it was disproportionately the better quality houses, in the more desirable areas that were sold. Moreover, research highlights that purchasers were systematically more advantaged than those households remaining as tenants. They were often middle-aged (and therefore had 
longer tenancies with greater discounts), and more likely to be economically active. The uptake of the RTB by the most affluent tenants has therefore left behind a council sector that is increasingly dominated by low-income groups, who are often out of the labour market and welfare dependent (Forrest and Murie 1988). It has now become largely the preserve of the old and young on low-incomes (Jones 2004). In Scotland, "almost three-quarters have incomes below $£ 15,000$ a year and two-thirds are dependent to some extent on housing benefit" (SG 2007: 35).

Whilst neighbourhoods may have benefited from tenure-mix and the retention of more affluent households (Atkinson and Kintrea 2000), the presence of owneroccupiers also represents a challenge for regeneration agencies, especially where 'low-income or reluctance' hinders landlord-led physical renewal (Munro 2007). In addition, research indicates that council house re-sales are impacting on different areas in different ways. The degree to which ex-council houses are integrated into the more general private housing market ultimately depends on the location of the dwelling, with those in less pressured markets, and less popular stock, remaining distinct from mainstream owner-occupation (Munro 2007). Local and regional variations are clearly visible in the re-sale market.

It is however, the impact on the social rented sector that has been the most significant. The loss of over 2 million public sector homes has ultimately reduced the number of properties available for let, with the loss of the most desirable homes in particular serving to undermine the availability of good family housing. This has severe implications for the most vulnerable households who cannot afford to purchase on the open market, as well as the capacity of social landlords to meet housing need and homeless obligations (Goodlad and Atkinson 2004). It is a key issue in Scotland given the more progressive nature of the homelessness legislation and the ambitious 2012 target of ending homelessness (Fitzpatrick 2004). Nonetheless, some commentators have argued that the sector was already in decline prior to the introduction of the RTB, and that other important housing policies such as the 1977 Housing (Homelessness) Act had already instigated a change in the demographic profile of social housing tenants (King 2010).

A further 'unexpected development' of the RTB has been its impact on the private rented sector (Jones 2010). Re-sales of council houses have been made to private landlords, or have been let directly by purchasers. As Munro (2007) notes this not only frustrates the goal of increasing local homeownership, but may also facilitate 
lettings to 'undesireable' tenants (such as students), as well as create landlords with little enthusiasm for investing in the upkeep of the property.

The remainder of this paper draws on an analysis of key government policy documents at the devolved level in order to illuminate the nature of 'modernising' reforms to the RTB, and the impact this has on social housing more generally.

\section{Devolution and the 'Modernised' Right to Buy}

The Scottish Parliament was formed in 1999 and initially led by a Labour-Liberal Democrat coalition. The devolved administration, known then as the Scottish Executive, has control over public policy areas such as health, education, and housing and has limited tax raising powers; key areas of government remain however the preserve of the UK Parliament in Westminster, most notably issues relating to social security, defence and taxation (Kintrea 2006). ${ }^{1}$

In the first term of the parliament, housing was elevated as a key policy priority. The 2001 Housing (Scotland) Act introduced a number of key pieces of legislation, including reforms to the RTB (HMSO 2001). This created a 'modernised' RTB for all social housing tenants (including housing associations), following the introduction of a single Scottish Secure Tenancy across the social rented sector in September 2002. The qualifying period for the RTB was also extended to five years (instead of two), and the maximum available discount reduced to thirty-five percent or $£ 15,000$, whichever is lowest. Existing public sector tenants however had their rights protected and continue to remain eligible under the previous RTB provisions, with exemptions also available for charitable associations. Another key provision of the act was a new mechanism, which enabled local authorities to apply to the Scottish Executive for 'pressured area' status. If the local authority can demonstrate a shortage of affordable housing then the RTB can be suspended for new tenants for up to five years. So far, fourteen out of thirty-two local authorities have been successful in applying for pressured area status (SG 2009). Whilst this serves to retain the stock of affordable housing for rent, it does undermine the ability to retain the more affluent aspiring homeowners who have had their RTB restricted (Kintrea 2006). Those households who are economically active may therefore choose to migrate from the local area in search of homeownership opportunities elsewhere, which is likely to have a significant impact on the local economy of the area. In a Scottish context, Glasgow provides a good example of this. Indeed the city's most recent Local 
Housing Strategy, identifies tenure-mix as having an important role in stemming outmigration into neighbouring authorities (McIntyre and McKee, 2008).

Whilst these modernising reforms introduced variations in the rights of social housing tenants in Scotland, it nonetheless signalled an attempt by the Scottish Executive to reconcile the aspirations of low-income households for homeownership, with the wider needs of local communities, and the obligations of local authorities to

meet housing need. Despite reducing the attractiveness of the RTB, and now boasting the lowest available discount in the UK, critics have suggested the reforms are modest, and not as significant as the changes adopted in England by the New Labour government, which reduced the maximum discount for all public sector tenants to $£ 16,000$ (Jones 2004). Given the majority of RTB sales took place in the 1980s it could be argued that these regional restrictions are being introduced at a time when it is now 'politically safe' to so, and where the effects are likely to be limited (King 2010).

\section{The SNP and the Housing (Scotland) Bill}

Following the election of the minority SNP administration in 2007, the RTB has continued to be scrutinised, and reforms have been on the Scottish Government's agenda since the publication of the discussion document Firm Foundations in 2007. This signals an attempt by the SNP to safeguard the remaining stock of social housing, and in doing so, re-balance individual aspirations for homeownership with the requirement of those whose needs are best met in social housing:

We want to reform RTB to strike a better and fairer balance between tenants who wish to own their own home and the needs of prospective tenants for social rented accommodation (SG 2009: 13).

The current Housing (Scotland) Bill proposes to end the RTB for both new social tenancies and new social housing in order to protect the local supply of affordable housing. This means that all newly built and newly acquired housing being let as social housing for the first time will be exempt, with the bill also ending the RTB for all new tenants who enter the sector after a specific date. Reforms to procedures for 'pressured area' status are also being considered, in order to increase the maximum designation period from 5 to 10 years, and to allow for the protection of particular 
house types. Measures to introduce more flexibility and local control over the designation of 'pressured area' status are also proposed (see also, SPICe 2010).

However, the draft bill acknowledges that these proposals may have a negative impact on the financial position of social landlords:

In the short term, there would be a fall in income from sales which would be offset in the longer term by continuing rental income from properties that might otherwise have been sold (SG 2009: 14).

This is because social landlords use the income generated from RTB sales to fund improvements to existing stock, and in particular to meet the requirements of the Scottish Housing Quality Standard (the Scottish equivalent of the Decent Homes Standard). ${ }^{2}$ In the long-term, the end of income from sales will have significant impact on business plans and may lead to rising rents in order to address shortfalls (Jones 2010; CIH Scotland 2009). Consequently, there have been calls to temper this blanket national policy by giving social landlords local flexibility to opt out of these provisions (CIH Scotland 2009). It should be noted however that the RTB is itself a barrier to investment, for social landlords (local authorities in particular) are unlikely to be willing to build new housing only for them to be sold off (Jones 2010). The loss of RTB sales receipts will however be offset over the long term by the rental income from social housing that otherwise might have been sold.

By ending the RTB the SNP are signifying their commitment to encourage both new investment and new building within the sector:

We estimate that the full package of the reforms that we outline below could reduce sales by about 20 percent. Therefore, depending on how the economy fares and its impact on future housing conditions, our reforms could mean we retain an extra 10,000 to 18,000 homes for social rent between 2012 and 2022. Also, RTB has in the past discouraged councils from building houses. Reforming RTB represents an important part of our initiative to encourage new council house building and retain these properties for future generations (SG 2009: 14).

Nonetheless, by continuing to preserve the rights of existing tenants it can be argued that the bill does not go far enough. The SNP have maintained they will not remove existing RTB entitlements, and indeed commentators have highlighted the 'sacrosanct' nature of the RTB and the possibility that any attempt to diminish the rights of existing tenants may be problematic and subject to legal challenge (Goodlad 
and Atkinson 2004). Despite this, the Scottish Government expect that over time those tenants eligible under the original RTB provisions will become smaller and smaller, and the scheme consigned to history.

\section{Social Housing in Scotland: the way ahead}

Despite a political will to end the RTB, there nonetheless remains a lack of clarity about the precise role the Scottish Government envisages for the social rented sector. Whilst recent consultation papers suggest a commitment to social housing, they do not embrace any radical or revitalised future for the sector. Instead, the Scottish Government has largely accepted its marginal role as 'welfare housing' that provides help to vulnerable groups at particular times in their lives, as opposed to being a proactive choice and mainstream option (McIntyre and McKee, In Press):

... the last 25 years have seen the role of social landlords change from that of meeting general housing needs to being increasingly the providers of homes for the most vulnerable in society. This trend appears likely to continue, with owner occupation remaining the tenure of choice for the majority (SG 2007: $34)$.

Whilst Firm Foundations suggests that social housing could extend its role to include middle-market rented accommodation, targeting a niche who cannot access traditional social housing but for whom owner-occupation is unaffordable, there have been no firm developments on this front (SG 2007: 45). Yet as long as the sector remains the preserve of the poorest, most vulnerable members of society, it will find it difficult to shake off its negative image as a 'tenure of last resort'. As Kintrea (2006) argues, in order to protect social housing tenants from 'social isolation and stigma' greater efforts are needed to widen access to the sector and diversify the social mix of its tenant base. This would require a much more confident social rented sector, serving the needs of a wider cross-section of society than it does at present. This goal becomes even more important when we consider the requirements of the Homelessness Etc. (Scotland) Act 2003, which abolishes priority need and gives all unintentionally homeless households an entitlement to permanent accommodation. As Kintrea (2006: 198) comments: 
If the reforms are successful in assisting homeless people, this will not only put further pressures on housing supply in the more pressured areas of Scotland, as the Scottish Executive itself has appreciated, but it also seems likely to further increase the proportion of people in social housing living in poverty, particularly in the less popular estates with poorer housing conditions which will effectively be the more accessible to homeless people.

Given Scotland's traditionally larger social housing sector, which at its peak in 1981 housed fifty percent of the population (SG 2007: 35), renting from a social landlord has never had the same stigma as elsewhere in the UK. It would be a disappointing development if this were to change. However, if the Scottish Government fails to intervene and proactively widen the tenant base within the social rented sector it is difficult to see how its future can be anything other than a tenure for society's most vulnerable. Analysis of the SCORE data collected for the Scottish Government highlights that the percentage of social housing lets allocated through the statutory homeless route has more than doubled in recent years, rising from 12 percent in 2003/04 to 28 percent in 2009/10 (SCORE 2010). The spatial concentration of such vulnerable households within social housing estates clearly has implications for local economic development in terms of the disposable income available in the local community to support business and other services.

The end of the RTB also has implications for community cohesion agendas, for it ultimately limits the opportunity to mix tenures at the local level through lowcost homeownership initiatives (SPICe 2010; Kintrea 2006). Despite the recent policy push towards shared equity schemes, these are more complex to administer, and are dependent on the availability of sub-prime mortgages (Author 2010), which are likely to be scarce post credit-crunch. Although the academic community remains divided over the benefits of tenure-mix (see for example, McIntyre and McKee, In Press), reducing opportunities for low-cost homeownership (and thereby mixed-tenure estates) runs the risk of the Scottish Government countering its own objective to tackle concentrations of disadvantage that are prevalent in Scotland's social housing estates:

In the eyes of many at least ... social housing has become stigmatised. It is viewed by many as being too closely associated with unpopular and unsatisfactory neighbourhoods ... The most deprived $15 \%$ of neighbourhoods are characterised by high concentrations of social housing and more generally ... there appears to be a strong correlation between concentrations of social housing and deprivation (SG 2007: 36-37). 
This highlights the policy tensions that are being created by the proposed reforms to the RTB. Whilst protecting the nation's supply of social housing provision is an admirable political ambition it nonetheless has implications for, and may run counter to, other government policy agendas.

Perhaps the overriding problem, as Kintrea (2006: 201) asserts, is the devolution settlement itself. Key areas of government, "notably housing benefit and the financial attractions of homeownership, which is shaped by the tax system" remain the preserve of Westminster, and this ultimately undermines the ability of the Scottish Parliament and the Scottish people, to propose a more radical future for social housing.

\section{Conclusion}

The RTB remains one of the most popular, but also one of the most controversial housing policies of the post-war era. Whilst it has delivered a range of positive benefits to both individuals and communities in terms of wealth creation and tenuremix, it has also prompted the decline of the social rented sector, thereby undermining the ability of social landlords to meet housing need, and contributed to the spatial concentration of poverty and disadvantage within social housing estates. Following the creation of the Scottish Parliament in 1999, subsequent devolved administrations have endeavoured to 'modernise' this policy by reducing its attractiveness. This has resulted in regional and local variations across the UK concerning tenants' 'right' to buy. Whilst efforts to preserve the nation's stock of affordable housing are to be welcomed, especially during these difficult financial times, the measures have arguably come too late to transform the future of the social housing sector, especially as they do not apply to all social housing tenants. Moreover, ending the RTB and thereby opportunities for low-cost homeownership, may actually work against other government objectives such as those focused on creating stronger, more cohesive communities. Simply ending the RTB is not sufficient to revitalise the social rented sector and address the problems plaguing Scotland's most deprived communities. What is needed is a much more tenure-neutral approach to housing policy, which promotes a more radical future for the social rented sector and does not simply consign it to its current role of 'welfare housing'. 


\section{Endnotes}

${ }^{1}$ In 2007 following the election of the minority SNP administration, the Scottish Executive was rebranded as the Scottish Government.

2 The Scottish Housing Quality Standards is a set of criteria that all social landlords must meet by 2015 , with regards to the physical standard of their properties.

\section{Acknowledgements}

Thanks to the Editor and two anonymous referees from Local Economy, and colleagues from the Centre for Housing Research at St Andrews who provided helpful comments on the paper, as well as to the SCORE team who provided vital contextual information.

\section{References}

Atkinson, R. and Kintrea, K. (2000) "Owner-occupation, Social Mix and Neighbourhood Impacts”, Policy and Politics 28(1): 93-108.

Chartered Institute of Housing Scotland (2009) "Reforming the Right to Buy in Scotland A Capital Investment? A Briefing Paper" [online]. Available at: http://www.cih.org/scotland/policy/RTB-BriefingPaperSept09.pdf [Accessed 3 March 2010].

Fitzpatrick, S. (2004) "Homelessness Policy in Scotland”, pp.183-198, in Sim, D. (ed.) Housing and Public Policy in Post-Devolution Scotland. CIH: Coventry.

Forrest, R. and Murie, A. (1988) "Selling the Welfare State: the privatisation of public housing." London: Routledge.

Forrest, R. (2010) A Privileged State? Council Housing as a Social Escalator, pp. 37 58, in P.Malpass and R.Rowlands (eds) Housing, Markets and Policy. London: Routledge.

Goodlad, R. and Atkinson, R. (2004) "Sacred Cows, Rational Debates and the Politics of the Right to Buy after Devolution”, Housing Studies 19 (3): 447- 463. 
Her Majesty's Stationary Office (HMSO) (2001) "Housing (Scotland) Act 2001" [online]. Available at:

http://www.hmso.gov.uk/legislation/Scotland/acts2001/20010010.htm [Accessed 3 Match 2010].

Jones, C. (2004) "Reforming the Right to Buy" p 52-63, in Sim, D. (ed.) Housing and Public Policy in Post-Devolution Scotland. CIH: Coventry.

Jones, C. (2010) “The Right to Buy”, p59-75, in P.Malpass and R.Rowlands (eds) Housing, Markets and Policy. London: Routledge.

King, P. (2010) "Housing Policy Transformed: the right to buy and the desire to own". Policy Press: Bristol.

Kintrea, K. (2006) "Having it All? Housing Reform under Devolution" Housing Studies, 21 (2): 187-207.

McIntyre, Z. and McKee, K. (2008) "Governance and Sustainability in Glasgow: connecting symbolic capital and housing consumption to regeneration", Area 40 (4): 481- 490 .

McIntyre, Z. and McKee, K. (In Press) "Creating Sustainable Communities through Tenure-mix: the responsibilisation of marginal homeowners in Scotland", Geojournal.

McKee, K. (2010) "Low Cost Homeownership Schemes in Scotland: promoting sustainable homeownership?" conference paper presented at the Housing Studies Association conference, University of York, April 2010.

Munro, M. (2007) "Evaluating Policy Towards Increasing Owner Occupation", Housing Studies, 22 (2): 243- 260.

Saunders, P. (1990) “A Nation of Home Owners”. London: Unwin Hyman. 
SCORE (2010) “Trends in Statutory Homeless Lets in Scotland”. Personal Communication.

Scottish Government (2007) "Firm Foundations: the future of housing in Scotland: a discussion document [online]". Available at:

http://www.scotland.gov.uk/Publications/2007/10/30153156/0 [Accessed 3 March 2010].

Scottish Government (2009) "Draft Housing (Scotland) Bill: a consultation [online]". Available at: http://www.scotland.gov.uk/Publications/2009/04/27095102/12 [Accessed 3 March 2010].

SPICe (2010) "SPICe briefing: Housing (Scotland) Bill [online]". Available at: http://www.scottish.parliament.uk/business/research/briefings-10/SB10-19.pdf [Accessed 3 March 2010]. 